\title{
The Effects of Situational Teaching, Cooperative Learning, and Self-directed Learning on Mathematical Learning Abilities in China
}

\author{
Chen Lei \\ Dept. of Foundation of Education \\ Faculty of Educational Studies, Universiti Putra Malaysia, \\ 43400 Serdang, Malaysia. \\ Fazilah Razali (Corresponding Author) \\ Dept. of Foundation of Education \\ Faculty of Educational Studies, Universiti Putra Malaysia, \\ 43400 Serdang, Malaysia.
}

Received: Oct. 3, $2021 \quad$ Accepted: Nov. 5, $2021 \quad$ Online published: Nov. 24, 2021

doi:10.5296/ijhrs.v11i4S.19247ＵRL: https://doi.org/10.5296/ijhrs.v11i4S.19247

\begin{abstract}
The junior high school stage is a significant stage of education because students thinking skills develop the fastest in junior middle school. In addition, the quality of junior high school education impacts the students learning ability, especially in mathematics, and the teaching methods also play a key role in students' mathematical learning ability. Therefore, this research explores the impact of problem-based learning on junior high school students' mathematical learning ability, and studies their impact on students' mathematical learning ability from the core principles of problem-based learning, including learning situations, cooperative learning, and self-directed learning. A total of 240 students from Meixi Lake Changjun Middle School participated in this research based on quantitative research methods collected of such as the "Mathematical Ability Scale" and other questionnaires. The correlation analysis revealed that situational teaching, self-directed learning and cooperative learning have a moderately positive correlation with students' mathematical abilities. In this study, an independent sample t-test analyzed the significant correlation between gender and mathematical learning abilities. This research aims to find better learning methods to improve
\end{abstract}


the mathematical learning abilities of Chinese junior high school students and their performance in mathematics subjects.

Keywords: problem-based learning, situational leaching, cooperative learning, self-directed learning, Mathematical Learning Abilities, junior high school students, China

\section{Introduction}

\subsection{Background of the Study}

1) Mathematics is an important subject as well as a problem-solving tool. It is based on logic and develops critical thinking skills focused on methods to solve practical problems. The focus of the education system in China has now shifted from being exam-oriented to competence education. In this transition process, the main objective of is to significantly improve the quality of mathematics learning of the entire nation by cultivating people's ability to solve problems from a mathematical viewpoint (Zhang, 2012). Under the new historical conditions, activities in mathematics education must not only answer the question of "how to teach", but also explore ready-made teaching materials and methods to answer the questions of "what to teach" and "how to learn". In other words, new theories need to address this urgent need. On the other hand, the college entrance examination is highly competitive, and math scores account for a large proportion of the college entrance examination. Therefore, improving mathematics teaching methods and strengthening students' mathematical learning abilities have become the main focus of teachers and students.

\subsection{Problem Statement}

He (2011) observed that junior high school students are in a period of rapid growth of knowledge and wisdom and that a good foundation in mathematics at the junior high school stage is important for the future. However, there are two extremes in the performance of Chinese students; some students are excellent learners while others lack sufficient learning skills, which also leads to a loss of interest in learning mathematics (Bai, 2014). In addition, students do not engage in sufficient group discussions in the classroom. The current junior middle school mathematics teaching model is focused on the individual student and group participation is not high (Pepin et al., 2017).

\subsection{Purpose of the Study}

\subsubsection{General Objectives}

The research explores the impact of problem-based learning (PBL) as an alternative mathematics teaching strategy for students in junior middle school by examining the relationship between the core principles of problem-based learning and the formation of students' mathematical learning abilities. In addition, the research seeks to construct a basic model suitable for classroom teaching of mathematics in junior high school through the analysis of problem-based learning principles and factors that improve students' mathematical learning abilities. 


\section{Macrothink}

\subsubsection{Specific Objectives}

The specific objective is to solve the following problems:

1. Investigate the effect of situational teaching on students' mathematical learning ability.

2. Investigate the effect of cooperative learning on students' mathematical learning ability.

3. Examine the effect of self-directed learning on students' mathematical learning ability.

4. Explore the significant differences between students' mathematical learning ability and gender.

\subsection{Research Questions}

1. What is the effect of situational teaching on students' mathematical learning ability?

2. What is the effect of cooperative learning on students' mathematical learning ability?

3. What is the effect of self-directed learning on students' mathematical learning ability?

4. What are the significant differences between students' mathematical thinking ability and gender?

\subsection{Research Hypothesis}

The following are the hypotheses of this research:

H1: There is no significant effect between situational teaching and mathematical learning ability.

$\mathrm{H} 2$ : There is no significant effect between cooperative learning and mathematical learning ability.

H3: There is no significant effect between self-directed learning and mathematical learning ability.

H4: There is no significant difference between the strength of students' mathematical learning ability and gender.

\subsection{Significance of Research}

Theoretical significance: From a theoretical perspective, studying the impact of problem-based learning on students' mathematical ability expands the theoretical system of mathematics learning methods. With the in-depth research on thinking abilities and generalization of the factors affecting students' mathematical ability, students can improve their mathematical learning ability. In addition, there is an increasing trend among junior high school students in China that tend to be partial towards certain subjects, especially mathematics. The main reason for this phenomenon is the failure to develop students' mathematical learning abilities. This study explores the ways to form efficient mathematics learning skills based on the relationship between problem-based learning and students' mathematical learning ability to change the status quo of mathematics learning. 
Practical significance: This research will change the status quo of mathematics teaching in junior high schools in China, put students on the right track, and stimulate their desire for learning and spirit of exploration. Formulating the correct teaching methods to improve students' mathematical learning ability not only brings changes in academic performance and improves students' learning ability in mathematics but also other subjects, such as physics and chemistry. In addition, the main goal of most students in China is to pass the college entrance examination to enter a top university for a better future in the college entrance examination, mathematics is one of the main subjects that require a high score. Therefore, performing well in mathematics is the key to ace the college entrance examination.

\subsection{Limitations of Study}

1. Due to limited funding and time constraints, only urban junior high schools participated in the survey.

2. Due to the strict rules by the Chinese government on the presence of foreign personnel in schools, the only research methods used were interviews or questionnaires.

3. Due to the small number of students and limited time to participate in the survey, this study used simple questionnaires.

\section{Literature Review}

\subsection{Conceptual Definitions}

Mathematical learning ability is the ability to grasp mathematical knowledge, skills and habits relatively quickly, easily and thoroughly (Cardelle-Elawar, 1992). In this study, the standards of the mathematics teaching curriculum pointed out that thinking ability mainly refers to being able to observe, experiment, compare, guess, analyze, synthesize, abstract, and generalize, as well as reason with induction, deduction, and analogy. In other words, students learn to be logical through mathematical concepts, ideas, and methods that identify mathematical relationships.

Situational learning mainly refers to gaining knowledge through imagination, manual, oral, graphics, and other means (Zheng et al., 2017). Usually, this learning method will have different degrees of innovation with the development of the times. In this study, the learning context relates to the knowledge content but not another aspect of knowledge. It should be an event or scene that reflects the process of knowledge discovery, the conditions of application, and the meaning and value of knowledge in life. Only such a situation can effectively clarify the value of knowledge in real life, help students accurately understand the connotation of knowledge, stimulate their motivation and enthusiasm for learning, and prompt them to transform knowledge into skills.

Cooperative learning refers to mutual aid learning in which students have a clear division of responsibilities to complete common tasks (Aguanta Jr \& Tan, 2018). In the research, cooperative learning encouraged students to work together and realize their goals in completing common tasks. Group members used various methods such as discussion, brainstorming, experiments, surveys, etc., to work together to accomplish tasks or goals. 


\section{MInstitute Macrothink $_{\text {Int }}$}

International Journal of Human Resource Studies

ISSN 2162-3058

2021, Vol. 11, No. 4S

Self-directed learning is a process initiated by the individual to judge their own learning needs, form their own learning goals, seek human and material resources for learning, select appropriate learning strategies, and evaluate learning results (Cazan \& Schiopca, 2014). Learners are distinguished based on several factors such as social roles, professional characteristics, personal needs, integration of internal cognition and external management, independent learning goals, planning the learning process, seeking learning resources, selecting learning strategies and evaluating the effects of learning activities (Roslan et al., 2021).

\subsection{Conceptual Framework}

Figure 1 shows the research framework of the relationship between situational teaching, cooperative learning, self-directed study, and students' mathematical learning abilities. Thus, these three factors are assumed to be associated with students' mathematical learning abilities.

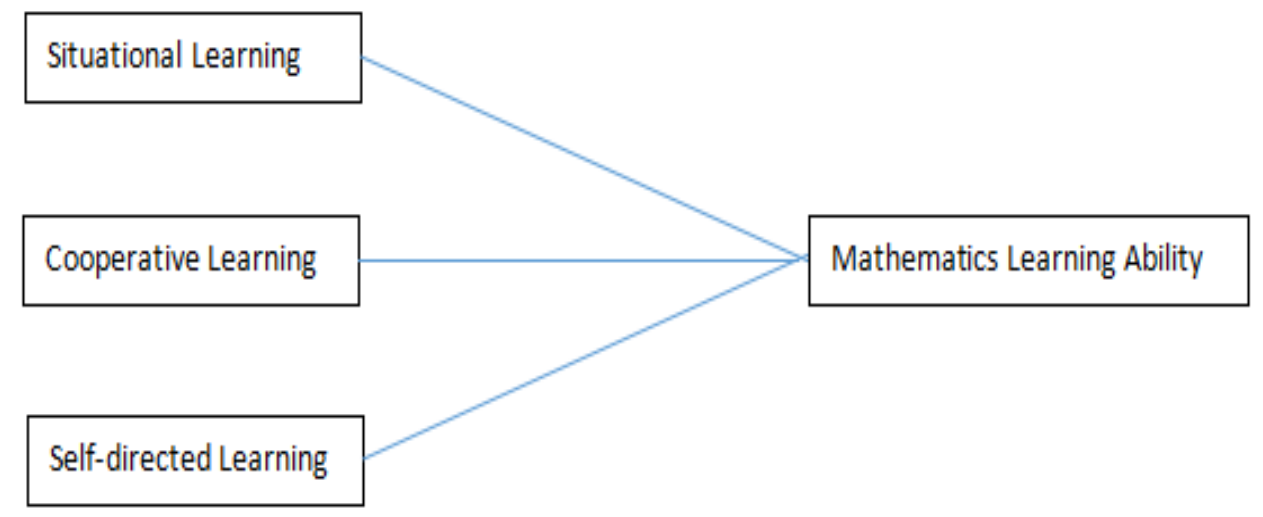

Figure 1. The conceptual framework

\subsection{Theoretical Study}

This research examines three theories (refer Figure 2), i.e., the situational learning theory, cooperative learning theory and constructivist theory. The situational learning theory holds that learning is not only an individual psychological process but also a social, practical, and participatory process mediated by different resources. It places great emphasis on the role of learners through interactions between learners and the learning situations, as well as other learners. Therefore, conducive learning situations establish the learners' identity and role, complete life experiences, and bring cognitive tasks to an integrated state.

The content of constructivist theory defined as student-centered emphasizes students' active exploration of knowledge, discovery, and construction of the meaning of knowledge (Hein, 1991). This theory believes in learning as a process of acquiring knowledge. Knowledge is not passively received but actively constructed through cognitive subjects. Learning is the process of meaningful construction achieved with the help of others (i.e., inter-personal collaborative activities) in a certain context (for example, cultural background). In this regard, 
meaningful construction associated with the teaching of mathematics provides a better understanding of the learning process - how learning occurs, how meaning is constructed, and how concepts are formed, and what factors contribute to an ideal learning environment.

The theory of cooperative learning is not only confined to study group activities as the basic form but also other forms of teaching activities through the interactive cooperation of dynamic factors (i.e., teacher and student) as the ability resource. All cooperative learning activities focus on achieving specific teaching goals. Therefore, cooperative learning regards interaction, goal, teacher-student relationship, form, context, and evaluation as basic concepts (Yang, 2003). Bai (2015) believed that cooperative learning mainly refers to the main organizational form of group learning in classroom teaching. According to certain cooperative methods, students are encouraged to study together in heterogeneous groups. In this regard, cooperative interpersonal communication promotes students' knowledge and skills, learning process and method, as well as the coordinated development of the teaching strategy system of emotion, attitude, and value. Yang (2010) believed the background, strength, and abilities of team members must be fully considered to lay the foundation for effective cooperation and role-play. During the discussion, students should give their explanations and play their roles well. In addition, students should also learn to coordinate and respect the roles played by others. It must be noted that students need to patiently listen to others and tolerate different opinions. This not only improves students' understanding of the content, but also cultivates their cooperative learning spirit (Zhao, 2014).

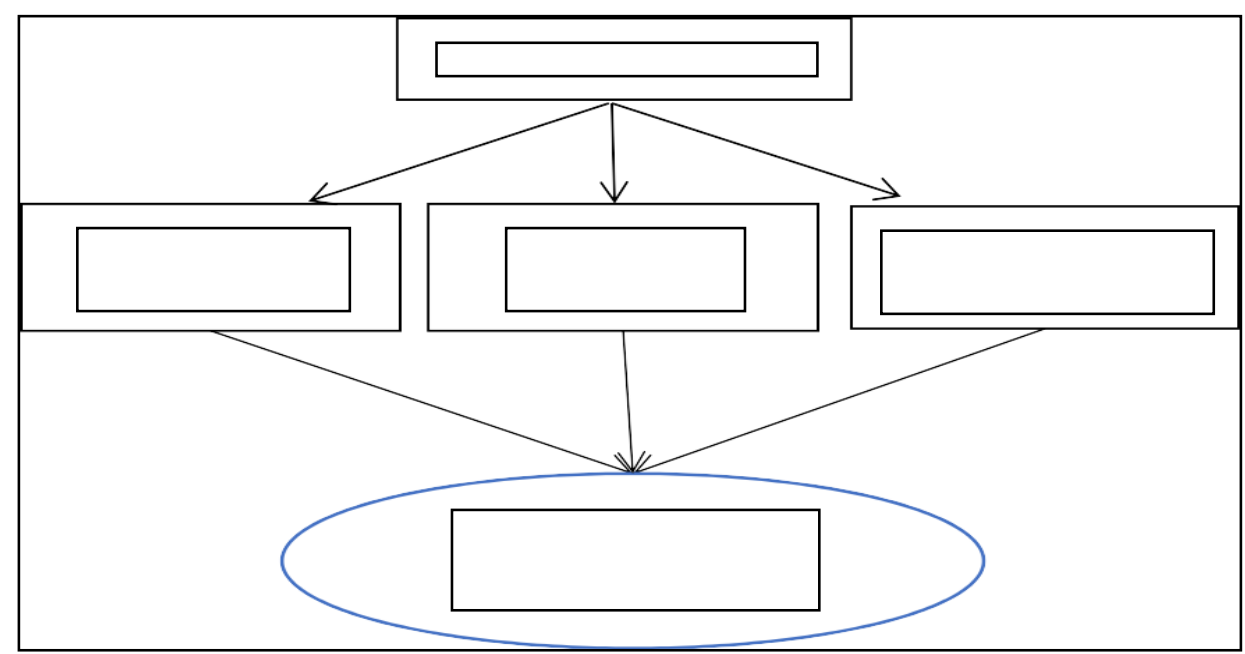

Figure 2. The theoretical of the study

\subsection{Review of Previous Studies}

Mathematics is relevant to our daily life, and the key to learning mathematics is by learning methods. Accordingly, wrong teaching methods would cause students to lose interest in mathematics and lack mathematical abilities or even mislead them (Yuliani, \& Saragih, 2015). Following a teaching method merely allows students to blindly accept content from the teacher, and in such a passive learning state students lose motivation (Othman et al., 2010). Therefore, mathematics teaching methods should focus on the students to encourage them to learn cooperatively and think positively.There are two important factors influencing academic achievements, self-esteem and learning approaches, and teacher should motivate student 
based on these factors (Senin M.S et al., 2007; Zaini et al., 2021). In this regard, the teachers' duty must connect mathematics to real-life situations to cultivate students' mathematical abilities to solve practical problems (Cerezo, 2004).

There are many ways to cultivate students' enthusiasm, motivation to learn, and improve students' mathematical abilities. The teacher's use of suitable teaching methods is fundamental. Asking appropriate questions, conducting problem discussions, and allowing students to think about problems in real-life situations can stimulate students to learn. Wang (2005) believed situational teaching as a new teaching method enabled students to gain a better understanding of the content in textbooks and enhanced the development of their comprehension skills. Contextualized teaching plays an irreplaceable role in junior high school mathematics. Teachers must pay attention to learning environments and stimulate students' curiosity and motivation in learning mathematics (Huang \& Li, 2006). In addition, teachers can implement games in situational teaching to encourage students to use their hands and feet to stimulate their mathematical abilities (Wang, 2018). In junior high school mathematics, the application of situational teaching is an increasing trend in the education system of the future (Rami et al., 2018; Crawford \& Witte, 1999).

Cooperative learning in which students actively participate in group discussions is also a suitable teaching method. Its purpose is to encourage students to concentrate and focus on their subjective initiative i.e. to master mathematical knowledge in a cooperative learning environment and improve mathematical abilities. The basic connotation of group cooperative learning in junior high school mathematics teaching should be that students actively adopt group study for mathematics subjects by determining the form of group so that the combined skill in acquiring mathematical knowledge achieves the goal of promoting the common progress of group members (Davidson \& Kroll, 1991). Cooperative learning makes the classroom atmosphere more harmonious, improves students' learning enthusiasm, and breaks the tradition of passive learning from merely taking down notes to the active involvement of students to think and explore during the teaching process (Gillies, 2016). In addition, cooperative learning focuses on the development of students' learning abilities. In the process of teaching mathematics, apart from mastering the knowledge, students should also be encouraged to learn independently. In the process of cooperation, students should feel the joy of learning, discover their value, increase motivation and the awareness of acquiring knowledge and collaborative skills, respect for the individual development of students, and promote the improvement of students' learning abilities and overall quality (Yang, 2013). Teachers should choose whether to apply cooperative learning according to different teaching content and goals. However, not every mathematics class should implement the cooperative learning method. Some mathematics problems still require students to think independently. Usually, some difficult problems should be included in the cooperative learning method (Zakaria, Chin \& Daud, 2010). In the cooperative learning model, teachers should control the classroom because, in group learning, students will have discussions, although it is inevitable that there will be people chatting. Teachers should maintain discipline to ensure the successful implementation of cooperative learning (Capar \& Tarim, 2015). The application of this teaching model aims to encourage top students to mentor other middle school students, 
especially students with learning difficulties, to achieve progress and reduce the performance gap (Leikin \& Zaslavsky, 1997). Hu (2015) believed that cooperative learning in the middle school mathematics teaching process meets the various needs of students. For example, the members of a group are equal and respect each other. To maintain mutual respect, every group member helps each other to realize their interpersonal communication needs.

Zhang (2010) believed that self-directed learning among junior high school students stimulates students' interest in acquiring knowledge, builds self-confidence and independent learning abilities, inspire positive thinking, imagination, creativity and team spirit. Zhao (2011) believed the development of self-directed learning turned on the personal surroundings of students. A relatively relaxed environment helps improve their learning efficiency. Students should adopt self-directed learning in learning mathematics according to their learning strategies and plansfor more flexibility and freedom in learning. In other words, self-directed learning is "a process initiated by the individual to judge their own learning needs, form their own learning goals, seek human and material resources for learning, select appropriate learning strategies, and evaluate learning results" $(\mathrm{Li}, 2003)$.

Self-directed learning is a process in which learners make plans to guide their learning activities. It emphasizes the autonomy of learners and corresponds to other forms of self-oriented learning (Chen \& Hu, 2013). Self-directed learning is the psychological process of learners related to the individual learners' abilities, traits, or confidence (Ding, 2013). Learners are those who can initiate learning on their own, proceed independently and apply basic learning skills, arrange appropriate learning steps, develop a plan to complete learning, and use spare time to further their knowledge (Sumantri \& Satriani, 2016). Orientation is a personality trait related to decision-making. Self-learners have a sense of responsibility. When they have problems to be solved or want to obtain specific skills and information, they filter relevant information to solve those problems and achieve their goals. Basically, the acquired skills and conceptual knowledge are self-evaluated (Kleden, 2015). Based on the literature review, mathematics is a subject that requires students to active learners. Students need to adopt independent and flexible thinking, etc. Teachers can help students actively participate in the learning process through situational teaching for better understanding, engaging in cooperative discussions to obtain more advanced ideas, and self-directed learning for students to gain flexibility. Therefore, the preliminary analysis shows that it is worth exploring whether the application of problem-based learning in teaching mathematics is conducive to improve students' mathematical learning abilities.

\section{Method}

\subsection{Nature of Study}

This research adopted a quantitative method to explore the influence of the basic principles of problem-based learning on students' mathematical abilities. The survey involved simple questionnaires for more convenient data collection from various student samples that revealed a high response rate among the respondents. This research mainly focused on quantitative research to explain the problem more scientifically and comprehensively. In this study, the quantitative research mainly relied on the Mathematical Learning Ability Scale, the 


\section{MInstitute ${ }_{\text {Ink }}^{\text {Macrothink }}$}

Level Scale of Situational Teaching, the Level Scale of Cooperative Learning Implementation, and the Level Scale of Self-directed Learning. For research content, this study explored the Chinese middle school student's mathematical abilities and the factors that affect these students' abilities.

\subsection{Population and Sampling Procedures}

The respondents in this research are junior high school students of Meixi Lake Changjun Middle School. Researchers used the random sampling method because stratified random samples reduced the biases in selecting cases and provided high satisfactory data. A total of 240 students were selected from three grades (Junior 1 to 3) of Meixi Lake Changjun Middle School with a population size of 1832 students participated in the survey. There are 24 classes in this school. Then, 10 students were randomly selected from each class. Finally, 140 male students and 100 female students were selected randomly, aged 11 to 15 years old, and the average age of a participant is about 12 years old.

\subsection{Instrument and Description}

This study relied on quantitative research to examine the research questions comprehensively. The quantitative research tools used in the questionnaires are discussed below.

\subsubsection{Mathematical Learning Ability Scale}

The international student evaluation project (PISA) assesses the knowledge and ability of 15 -year-old youths to enter society when their compulsory education is about to end. PISA's assessment includes reading abilities, mathematical learning abilities, and scientific abilities. The system involved youth from Hong Kong, Macau, Taipei, and Shanghai. This study focused on the mathematical learning abilities of junior high school students, i.e. the assessment of mathematical learning abilities of students aged 13-15. The mathematical learning ability evaluation system of the PISA project provided significant guidance for the evaluation of mathematical learning abilities of junior high school students in China. The evaluation of mathematical learning abilities based on the PISA project is established in three dimensions: mathematics content, mathematical learning abilities and the level of mathematical learning abilities. Mathematical abilities were divided into several elements such as mathematical argumentation, raising and solving mathematical problems, mathematical modeling, mathematical reasoning, mathematical representation, mathematical symbolization and formalization, mathematical communication, and the use of tools. The responses to the questionnaire were scored with a 5-point Likert Scale that represented the level of agreement to a statement i.e., strongly disagree, disagree, neither agree nor disagree, agree, and strongly agree (WYATT et al., 1987). A high score indicates strong mathematical abilities.

\subsubsection{The Level Scale of Situational Teaching}

Discussing real or professional-related issues should be the starting point for problem-based learning. Situational teaching emphasizes that learning should be in a variety of meaningful situations. In such a learning environment, students discover how to connect abstract ideas 
with real-life situations. Through this process of discovery, reinforcement and connection, students internalized new concepts. This study used a situational teaching application-level questionnaire to understand the degree of correlation between the mathematics curriculum of Chinese junior high school students and real life problems (Bai, 2014). The data derived from the answers of the students depicted the level of mathematics classroom situational learning. The questionnaire is based on a book about situational teaching: "Situational Teaching and Learning: What It Is and Why It's Here to Stay". The responses to the questionnaire were scored with a 5-point Likert Scale that represented the level of agreement to a statement i.e., strongly disagree, disagree, neither agree nor disagree (WYATT et al., 1987), agree, and strongly agree. A high score indicates a stronger degree of situational teaching.

\subsubsection{The Level Scale of Cooperative Learning Implementation}

Learners who participated in collaborative learning have common goals, relying on each other's contributions, evaluating each other's ideas, and supervising the work of team members to complete tasks and solve complex problems. This study used a cooperative learning questionnaire to investigate the implementation of cooperative learning of mathematics in Chinese classrooms. The questionnaire is based on a book about cooperative learning: "Cooperative Learning: Integrating Theory and Practice". The responses to the questionnaire were scored with a 5-point Likert Scale that represented the level of agreement to a statement i.e., strongly disagree, disagree, neither agree nor disagree, agree, and strongly agree. A high score indicates a stronger degree of situational teaching (WYATT et al., 1987). A high score indicates a higher frequency of using cooperative learning methods.

\subsubsection{The Level Scale of Self-directed Learning}

Self-directed learning is a systematic process of learning content through an organized, planned and integrated internal and external learning process. This study used a questionnaire to determine students' arrangement of learning plans, the selection of learning materials, the execution of learning plans, etc., to assess the degree of self-directed learning. The questionnaire is based on a book about self-directed learning: "Self-Directed Learning: Emerging Theory and Practice". The responses to the questionnaire were scored with a 5-point Likert Scale that represented the level of agreement to a statement i.e., strongly disagree, disagree, neither agree nor disagree, agree, and strongly agree (WYATT et al., 1987). A high score indicates a higher frequency of using self-directed learning methods.

\subsection{Validity and Reliability}

This study adopted the single-item and sum-related validity analysis. This method is used to measure the content validity of the scale. Content validity is also called surface validity or logical validity, and refers to whether the designed item represents the content or topic to be measured. The content validity is often evaluated by a combination of logical analysis and statistical analysis. Logical analysis generally involves researchers or experts judging whether the selected items "look" in line with the purpose and requirements of measurement. The statistical analysis adopts the correlation analysis to obtain the evaluation result, i.e., calculating the correlation between the efficiency of each item score against the total score to 
determine the significance of the correlation.

The correlation analysis was conducted between the three subscale and the total scale, as well as the correlation between the efficiency of each subscale and the total scale. The results obtained are shown in Table 1.

Table 1. Correlation matrix between situational teaching scale, cooperative learning scale, self-directed learn scale and total scale

\begin{tabular}{ccccc}
\hline & $\begin{array}{c}\text { Situational } \\
\text { teaching }\end{array}$ & $\begin{array}{c}\text { Cooperative } \\
\text { learning }\end{array}$ & $\begin{array}{c}\text { Self-directed } \\
\text { learning }\end{array}$ & Total scale \\
\hline Situational teaching & 1.000 & & \\
\hline Cooperative learning & 0.334 & 1.000 & 1.000 \\
\hline Self-directed learning & 0.402 & 0.462 & 1.000 \\
\hline Total scale & 0.653 & 0.766 & 0.811 \\
\hline
\end{tabular}

Table 2. The Correlation between Mathematical Ability Item

\begin{tabular}{|l|l|l|l|l|l|l|l|l|l|}
\hline & F1 & F2 & F3 & F4 & F5 & F6 & F7 & F8 & Total scale \\
\hline F1 & 1.000 & & & & & & & & \\
\hline F2 & 0.714 & 1.000 & & & & & & & \\
\hline F3 & 0.538 & 0.575 & 1.000 & & & & & & \\
\hline F4 & 0.597 & 0.579 & 0.731 & 1.000 & & & & & \\
\hline F5 & 0.738 & 0.642 & 0.447 & 0.484 & 1.000 & & & & \\
\hline F6 & 0.575 & 0.673 & 0.432 & 0.543 & 0.448 & 1.000 & & & \\
\hline F7 & 0.673 & 0.567 & 0.831 & 0.432 & 0.734 & 0.587 & 1.000 & & \\
\hline F8 & 0.692 & 0.675 & 0.763 & 0.831 & 0.773 & 0.564 & 0.675 & 1.000 & \\
\hline $\begin{array}{l}\text { Total } \\
\text { scale }\end{array}$ & 0.774 & 0.778 & 0.723 & 0.723 & 0.789 & 0.812 & 0.743 & 0.818 & 1.000 \\
\hline
\end{tabular}

This study also utilized the SPSS software analysis. The overall reliability of the measuring instruments (or questionnaires) was analyzed based on the Cronbach's coefficient values. The Cronbach coefficient method was named after the American educator, Lee Cronbach (1995), and recognized as the most commonly used reliability test. The Cronbach coefficient test is 
used to measure the consistency of the scores among the items in the scale. The coefficient value "applicable to attitudes, opinions, questionnaires or scale reliability analysis" is generally distributed between 0 and 1 (Gliem \& Gliem, 2003). Researchers generally regard the Cronbach coefficient value above 0.6 as an acceptable range, and if the coefficient value reached a value of 0.7-0.8, the scale had a high degree of credibility. If the coefficient value reached $0.8-1$, the the scale had good reliability. Table 3 summarizes the Cronbach's coefficient values of the four scales.

Table 3. Cronbach's a Coefficient Values on Four Scales

\begin{tabular}{llcc} 
& Study Variables & Number of Items & Cronbach alpha values \\
\hline $\mathbf{1}$ & Situational teaching & 10 & 0.807 \\
\hline $\mathbf{2}$ & Cooperative learning & 10 & 0.845 \\
\hline $\mathbf{3}$ & Self-directed learning & 10 & 0.767 \\
\hline $\mathbf{4}$ & Mathematical ability & 8 & 0.884 \\
\hline
\end{tabular}

\subsection{Data Collection Procedure}

This study used a questionnaire for the purposes of the survey. A random sampling method was used to record data from the selected middle school students of Meixi Lake Changjun Middle School. The questionnaire was distributed with the assistance of the school's teacher. After the student completed the test paper, the teacher compiled the data and sent it to the author. A total of 240 test papers were received.

\subsection{Data Analysis Method}

The total score of questionnaire results was calculated using a manual scoring method and entered into the WPS EXCEL. A preliminary analysis of the data was obtained through descriptive analysis using the SPSS software. The calculation included descriptive statistics, frequency, mean and standard deviation. In order to verify the correlation between mathematical learning abilities and gender attributes, the author used an independent sample t-test to investigate the differences between the principle of problem-based learning and mathematical abilities. In addition, the author used the One-way ANOVA analysis to analyze the relationship between mathematical learning abilities and mathematics levels. To investigate the relationship between situational teaching, cooperative learning, and self-directed learning, and students' performance and mathematical abilities, the author used the Pearson Correlation analysis method.

\section{Result}

\subsection{Reliability and Factor Analysis}

The results of the reliability analysis are shown in Table 4 . The degree of consistency of the results related to its reliability using the same method to evaluate all variables. The study 
used the Cronbach's coefficient values to determine reliability. Based on the Cronbach theory, it was found $a=0.874$. This value showed that all the items used in this study had excellent reliability. The validity analysis measured the validity of the data collected from the survey. In this study, the factor analysis was used to evaluate the structural validity of the entire questionnaire. According to table 4, $\mathrm{KMO}=0.783$ and indicated good validity of the questionnaire.

Table 4. Reliability and Factor Analysis

\begin{tabular}{llr}
\hline KMO and Bartlett's Test & & \\
\hline Reliability Analysis & $\begin{array}{l}\text { Cronbach's Alpha } \\
.874\end{array}$ & .783 \\
\hline Kaiser-Meyer-Olkin Measure of Sampling Adequacy. & 548.818 \\
\hline $\begin{array}{llr}\text { Bartlett's Test of } \\
\text { Sphericity }\end{array}$ & Approx. Chi-Square & 6 \\
\cline { 2 - 2 } & df & .000 \\
\hline
\end{tabular}

\subsection{The Demographic Profile}

The demographic profile of the respondents who participated in this study is shown in Table 5. The descriptive analysis of this study includes the following demographic data: (A) gender, and (B) mathematics level. Out of the 240 respondents who participated in the study, 100 were female students and 140 were male students. The report showed that 30 respondents reached Level 1, 120 respondents reached Level 2, and 90 respondents reached Level 3. Among these levels, Level 3 represented the highest level, i.e., good mathematical abilities, followed by Level 2. Level 1 represents the lowest level of mathematical abilities. The level is derived from the student's final exam scores in an earlier study. The math score below 72 points fall in Level 1, scores of 73-100 points fall in Level 2. Those with a score of 100 or higher fall in Level 3.

Table 5. Demographic Characteristics of Respondents

\begin{tabular}{cllccc}
\hline \multicolumn{5}{c}{ The demographic characteristics of respondents } \\
\hline \multirow{2}{*}{ Gender } & Frequency & Percent & Valid Percent & Cumulative Percent \\
& male & 140 & 58.3 & 58.3 & 58.3 \\
\cline { 2 - 6 } & female & 100 & 41.7 & 41.7 & 100.0 \\
\cline { 2 - 6 } Mathematics & Total & 240 & 100.0 & 100.0 & \\
\cline { 2 - 6 } level & Level 1 & 30 & 12.5 & 12.5 & 12.5 \\
\cline { 2 - 6 } & Level 2 & 120 & 50 & 50 & 62.5 \\
\cline { 2 - 6 } & Level3 & 90 & 37.5 & 37.5 & 100 \\
\hline
\end{tabular}




\subsection{Descriptive Statistics and Significance}

Independent t-test samples and one-way analysis of variance were performed on the values of each sample. This study used an independent sample t-test to explore the important relationship between gender and mathematical abilities. Table 6 shows the average value of the female samples is 4.0200 , and a standard deviation of 0.88740 . The average value of the male samples is 4.2143 with a standard deviation of 0.80274 . Therefore, $p=0.078>0.05$, indicated no significant difference in the mathematical abilities between sexes.

Table 6. Independent Sample T-test

\begin{tabular}{lc} 
Group & Mean \pm Std. Deviation \\
\hline Female $(\mathrm{N}=100)$ & $4.0200 \pm 0.88740$ \\
Male $(\mathrm{N}=140)$ & $4.2143 \pm 0.80274$ \\
\hline $\mathrm{t}$ & 1.769 \\
$\mathrm{p}$ & 0.078 \\
\hline
\end{tabular}

\subsection{One-way ANOVA Analysis}

A one-way analysis of the variance was undertaken to determine significant differences between the proficiency in mathematics and mathematical learning abilities. According to the basic descriptive statistics in Table 7, the math level is divided into three levels, with a total of 30 students at Level 1 . The average score of the tested mathematical learning ability is 2.65with a standard deviation of 0.874. There are 120 students in Level 2, and the average score of the tested mathematical learning ability is 3.35 with a standard deviation of 0.843 . The mean scores on the mathematical learning ability test were 4.28 with a standard deviation of 0.820 .

Table 7. One-way ANOVA analysis

\begin{tabular}{ccccc}
\hline Mathematics Level & N & Mean \pm Std. Deviation & F & P \\
\hline Level 1 & 30 & $2.65 \pm 0.874$ & & \\
Level 2 & 120 & $3.35 \pm 0.843$ & 6.952 & 0.046 \\
\hline Level 3 & 90 & $4.28 \pm 0.820$ & & \\
\hline
\end{tabular}

In a one-way ANOVA analysis, the level of math and mathematical learning ability is 6.952, $\mathrm{P}=0.046<0.05$. It follows that the null hypothesis must be rejected because the results showed a significant difference between math levels and math learning abilities.

\subsection{Pearson's Correlation Coefficient Analysis}

A Pearson correlation return value between - 1 and + 1indicates a strong negative correlation, whereas a value of +1 means strong positive correlation, and a value of 0 means no 


\section{Al Macrothink}

International Journal of Human Resource Studies

ISSN 2162-3058

2021, Vol. 11, No. 4S

correlation (also known as zero correlation). For $\alpha$ at the level of 0.05 , the results showed (see Table 8) a significant moderate positive correlation between situational teaching and mathematical learning abilities, $\mathrm{R}(240)=0.566, \mathrm{P}=0.000<0.05$. At the same time, there was a high positive correlation between cooperative learning and mathematical learning abilities, $\mathrm{R}(240)=0.715, \mathrm{P}=0.001<0.05$. There was a moderate positive correlation between self-directed learning and mathematical learning abilities, $\mathrm{R}(240)=0.683, \mathrm{P}=0.000$ $<0.05$. In other words, the three independent variables have a positive correlation with mathematical learning abilities.

Table 8. Correlations Analysis

\begin{tabular}{llc}
\hline & & Mathematical Learning Ability \\
\hline \multirow{2}{*}{ Situational Teaching } & Pearson Correlation & $.566^{* *}$ \\
& Sig. (2-tailed) & .000 \\
& $\mathrm{~N}$ & 240 \\
\hline Cooperative Learning & Pearson Correlation & $.715^{* *}$ \\
& Sig. (2-tailed) & .000 \\
& $\mathrm{~N}$ & 240 \\
\hline \multirow{2}{*}{ Self-directed Learning } & Pearson Correlation & $.638^{* *}$ \\
& Sig. (2-tailed) & .000 \\
& $\mathrm{~N}$ & 240 \\
\hline$* \star$ Correlation is significant at the 0.01 level (2-tailed).
\end{tabular}

\subsection{The Overall Hypothesis Result}

The results of the study found no significant difference between students' mathematical ability and gender. In addition, the Pearson correlation analysis revealed that situational teaching, self-directed learning, and positive mathematical learning abilities have a moderately positive correlation, and cooperative learning had a highly positive correlation with mathematical learning abilities. The overall hypothesis test results are summarized in Table 9.

Table 9. Overall Hypothesis Test Results

\begin{tabular}{|c|c|c|}
\hline No & Hypothesis & Accepted/Rejected \\
\hline 1 & $\begin{array}{l}\mathrm{H}_{1} \text { : There is no significant effect between situational teaching and } \\
\text { mathematical learning ability. }\end{array}$ & Rejected \\
\hline 2 & $\begin{array}{l}\mathrm{HO}_{2} \text { : There is no significant effect between cooperative learning and } \\
\text { mathematical learning ability. }\end{array}$ & Rejected \\
\hline 3 & $\begin{array}{l}\mathrm{HO}_{3} \text { : There is no significant effect between self-directed learning and } \\
\text { mathematical learning ability. }\end{array}$ & Rejected \\
\hline 4 & $\begin{array}{l}\mathrm{HO}_{4} \text { : There is no significant difference between the strength of students' } \\
\text { mathematical learning ability and gender. }\end{array}$ & Accepted \\
\hline
\end{tabular}




\section{Conclusion}

This research proved that students with weak mathematical learning abilities should spend more time in a cooperative learning environment with other students in the class to stimulate their progress. Alternatively, such students should plan their learning tasks and practice self-directed learning. Teachers should also pay attention to situational teaching for students to ease into the learning process more quickly, deepen their concentration to learn in real situations, and improve their learning efficiency.

Based on the results of this research, the author proposes several suggestions to improve students` mathematical learning abilities.

(1) Improve students' mathematical learning abilities by improving the level of situational teaching

If teachers can effectively carry out situational teaching of teaching mathematics, they can make learning methods more flexible, promote divergent thinking, and improve mathematics ability. In other words, the development of situational teaching requires teachers to develop and utilize various teaching resources to improve their teaching ability and promote cooperation among teachers (Wang, 2016).

\section{(2) Increase opportunities for cooperative learning}

Teachers who provide students with opportunities for cooperative learning enhance students' classroom knowledge and sense of participation. The cooperative learning model enhances independent learning, practical application, cooperation, and mutual assistance among students. In addition, teachers should encourage students to actively participate in exploratory exchanges in the classroom by analyzing their classroom learning experience. Teachers should cultivate students' ability to analyze problems by creating opportunities for them to analyze problems, develop mathematical consciousness, and logical thinking. Students can learn from each other in the process of cooperative learning and overcome their weaknesses (Li, 2012). In short, teachers are the organizers and instructors of cooperative learning. They should coordinate the relationship between members of the study group and foster a sense of cooperation among students (Wang, 2018).

\section{(3) Instruct students to conduct self-directed learning.}

Self-directed learning is an autonomous learning method i.e. students choose their learning content. This method has various benefits such as developing students' interest in learning, independent thinking, problem-solving, and fostering innovative ability to promote personality development. More importantly, self-directed learning improves students' logical thinking and sustainable development of their learning abilities, expanding learning channels, enriching knowledge sources, improving self-planning abilities which in turn improve students' mathematical abilities. Therefore, middle school mathematics teachers should guide students towards self-directed learning rather than merely assigning learning tasks. Teachers should guide students appropriately and increase their motivation by creating real-life learning situations (Carle, 2006). 
(4) Treat male and female students equally

The findings of this research showed no significant relationship between gender and mathematical learning abilities. A common gender stereotype is that boys have better logical thinking skills. Female gender stereotypes include the general perception of girls being inferior to boys in mathematics and even intelligence (Zhang, 2014). These general misconceptions impact female students' perception of mathematics as they fear and have a negative outlook on the subject. Therefore, when girls encounter difficult math problems, they are likely to give up even if they are capable of solving the problem. This study proved there is no difference between boys and girls in terms of objective factors such as intelligence, memory, comprehension, etc., although there are psychological differences. Boys are more confident and interested in learning mathematics. On the contrary, female students are more sensitive and lack self-confidence in learning mathematics. Therefore, junior high school teachers should pay more attention to the psychological conditions of female students, treat boys and girls equally in the teaching process, and break the gender stereotypes of female students.

\section{References}

Anderson, C. A., Gentile, D. A., \& Buckley, K. E. (2007). Violent video game effects on children and adolescents: Theory, research and public policy. https://doi.org/10.1093/acprof:oso/9780195309836.001.0001

Bai, X. (2014). Research on problems and countermeasures in the connection of mathematics teaching between high school and junior high school. Tianjin: Tianjin Normal University, 2014.

Bai, Z. (2015). The application of cooperative learning in elementary school mathematics teaching. College Entrance Examination (Comprehensive Edition), (10), 49.

Beck, C. A. J., \& Sales, B. D. (2001). Family mediation: Facts, myths, and future prospects (pp. 100-102). Washington, DC: American Psychological Association. https://doi.org/10.1037/10401-000

Bernstein, T. M. (1965). The careful writer: A modern guide to English usage (2nd ed.). New York, NY: Atheneum.

Bjork, R. A. (1989). Retrieval inhibition as an adaptive mechanism in human memory. In H. L. Roediger III, \& F. I. M. Craik (Eds.), Varieties of memory \& consciousness (pp. 309-330). Hillsdale, NJ: Erlbaum.

Cardelle-Elawar, M. (1992). Effects of teaching meta cognitive skills to students with low mathematics ability. Teaching and teacher education, 8(2), 109-121. https://doi.org/10.1016/0742-051X(92)90002-K

Carle Witt, Carle Witt. (2006). Education essence and China's family education enlightenment, China Aerospace publishing house, first edition.

Cazan, A. M., \& Schiopca, B. A. (2014). Self-directed learning, personality traits and 
academic achievement. Procedia-Social and Behavioral Sciences, 127, 640-644. https://doi.org/10.1016/j.sbspro.2014.03.327

Cerezo, N. (2004). Problem-Based Learning in the Middle School: A Research Case Study of the Perceptions of At-Risk Females. RMLE Online Research in Middle Level Education. 27(1), 1-13. https://doi.org/10.1080/19404476.2004.11658164

Crawford, M., \& Witte, M. (1999). Strategies for Mathematics: Teaching in Context. Educational Leadership, 57(3), 34-38.

Cress, C. M. (2009). Curricular strategies for student success and engaged learning [PowerPoint slides]. Retrieved from http://www.vtcampuscompact.org/2009/TCL_post/presenter_powerpoints /Christine\%20Cress\%20-\%20Curricular\%20Strategies.ppt

Davidson, N., \& Kroll, D. L. (1991). An overview of research on cooperative learning related to mathematics. Journal for Research in Mathematics Education, 22(5), 362-365. https://doi.org/10.2307/749185

Ding, Y. (2013). Strategies and steps for self-directed learning. Research on the teaching of curriculum materials: Research on Chinese Education, (Z4), 88-88.

Driedger, S. D. (1998, April 20). After divorce. Maclean's, 111(16), 38-43.

Gibbs, J. T., \& Huang, L. N. (Eds.). (1991). Children of color: Psychological interventions with minority youth. San Francisco, CA: Jossey-Bass.

Gilbert, D. G., McClernon, J. F., Rabinovich, N. E., Sugai, C., Plath, L. C., Asgaard, G., ... Botros, N. (2004). Effects of quitting smoking on EEG activation and attention last for more than 31 days and are more severe with stress, dependence, DRD2 A 1 allele, and depressive traits. Nicotine and Tobacco Research, 6, 249-267. https://doi.org/10.1080/14622200410001676305

Gliem, J. A., \& Gliem, R. R. (2003). Calculating, interpreting, and reporting Cronbach's alpha reliability coefficient for Likert-type scales. Midwest Research-to- Practice Conference in Adult, Continuing, and Community Education.

Goleman, D. (2009). What makes a leader? In D. Demers (Ed.), AHSC 230: Interpersonal communication and relationships (pp. 47-56). Montreal, Canada: Concordia University Bookstore. (Reprinted from Harvard Business Review, 76(6), pp. 93-102, 1998).

Guignon, C. B. (1998). Existentialism. In E. Craig (Ed.), Routledge encyclopedia of philosophy (Vol. 3, pp. 493-502). London, England: Routledge.

Healey, D. (2005). Attention deficit/hyperactivity disorder and creativity: An investigation into their relationship (Unpublished doctoral dissertation). University of Canterbury, Christchurch, New Zealand.

Hein, G. (1991). Constructivist learning theory. Institute for Inquiry. Available at:/http://www. exploratorium. edu/ifi/resources/constructivistlearning. htmlS. 
Herculano-Houzel, S., Collins, C. E., Wong, P., Kaas, J. H., \& Lent, R. (2008). The basic nonuniformity of the cerebral cortex. Proceedings of the National Academy of Sciences, 105, 12593-12598. https://doi.org/10.1073/pnas.0805417105

$\mathrm{Hu}, \mathrm{S}$. (2012). The application of cooperative learning in the classroom teaching of primary school mathematics. Primary School Science (Teacher Forum), (3),10-17.

Huang, X., \& Li, K. (2006). Contextual design of mathematics curriculum. Curriculum. Textbook. Teaching method, (9), 39-43.

Kleden, M. A. (2015). Analysis of Self-Directed Learning upon Student of Mathematics Education Study Program. Journal of Education and Practice, 6(20), 1-6.

Klimoski, R., \& Palmer, S. (1993). The ADA and the hiring process in organizations. Consulting Psychology Journal: Practice and Research, 45(2), 10-36. https://doi.org/10.1037/1061-4087.45.2.10

Kubrick, S. (Director). (1980). The Shining [Motion picture]. United States: Warner Brothers.

Leikin, R., \& Zaslavsky, O. (1997). Facilitating student interactions in mathematics in a cooperative learning setting. Journal for Research in Mathematics Education, 331-354. https://doi.org/10.2307/749784

Li, N. (2012). Application of cooperative teaching in junior high school mathematics. Times education.

Li, Z. (2003). Self-directed learning-the dominant form of adult learning in the future. Journal of Adult Education College of Hebei University, 5(2), 43-45.

Liu, S. (2005, May). Defending against business crises with the help of intelligent agent based early warning solutions. Paper presented at the Seventh International Conference on Enterprise Information Systems, Miami, FL. Abstract retrieved from http://www.iceis.org/iceis2005/abstracts_2005.htm

MacIntyre, L. (Reporter). (2002, January 23). Scandal of the Century [Television series episode]. In H. Cashore (Producer), The fifth estate. Toronto, Canada: Canadian Broadcasting Corporation.

McLuhan, M. (1970a). Culture is our business. New York, NY: McGraw-Hill.

McLuhan, M. (1970b). From cliche to archetype. New York, NY: Viking Press.

Mellers, B. A. (2000). Choice and the relative pleasure of consequences. Psychological Bulletin, 126, 910-924. https://doi.org/10.1037/0033-2909.126.6.910

Pepin, B., Xu, B., Trouche, L., \& Wang, C. (2017). Developing a deeper understanding of mathematics teaching expertise: an examination of three Chinese mathematics teachers' resource systems as windows into their work and expertise. Educational studies in Mathematics, 94(3), 257-274. https://doi.org/10.1007/s10649-016-9727-2

Postman, N. (1979). Teaching as a conserving activity. New York, NY: Delacorte Press. 
Postman, N. (1985). Amusing ourselves to death: Public discourse in the age of show business. New York, NY: Viking.

Rami, A. M., Abdullah, R., \& Ariffin, W. J. (2018). Strengthening social capital: Local leader's strategy toward developing rural community. International Journal of Academic Research in Business and Social Sciences, 8(1), 765-774. https://doi.org/10.6007/IJARBSS/v8-i1/3846

Razali, F. (2021). Exploring Crucial Factors of an Interest in STEM Career Model among Secondary School Students. International Journal of Instruction, 14(2), 385-404. https://doi.org/10.29333/iji.2021.14222a

Roslan, S., Hasan, S., Zaremohzzabieh, Z., \& Arsad, N. M. (2021). Big Five Personality Traits as Predictors of Systems Thinking Ability of Upper Secondary School Students. Social Sciences and Humanities, 29(S1), 1-20. https://doi.org/10.47836/pjssh.29.s1.14

Semenak, S. (1995, December 28). Feeling right at home: Government residence eschews traditional rules. Montreal Gazette, p. A4.

Senin M. S, Mohd Norazmi Nordin, Fatin Razak, Robaisya Rahmat \& Muhd Zulhilmi Haron. The review of Adedeji Tella research of the impact of motivation on student's academic achievement and learning outcomes in mathematics among secondary school students in Nigeria. Turkish Journal of Physiotherapy and Rehabilitation, 32(3), 4682-4690.

Strobel, J., \& Van Barneveld, A. (2009). When is PBL more effective? A meta-synthesis of meta-analyses comparing PBL to conventional classrooms. Interdisciplinary journal of problem-based learning, 3(1), 4-17. https://doi.org/10.7771/1541-5015.1046

Strong, E. K. Jr., \& Uhrbrock, R. S. (1923). Bibliography on job analysis. In L. Outhwaite (Series Ed.), Personnel Research Series: Vol. 1. Job analysis and the curriculum (pp. 140-146). https://doi.org/10.1037/10762-000

Sumantri, M. S., \& Satriani, R. (2016). The effect of formative testing and self-directed learning on mathematics learning outcomes. International Electronic Journal of Elementary Education, 8(3), 507-524.

Wang, J. (2018). Cultivation of students' autonomous learning and cooperative inquiry ability in primary school mathematics teaching. Education observation, (10), 126 -130.

Wang, S. (2005). Contextual cognition and contextual teaching design. Contemporary Educational Science, 1(24), 36-38.

Wang, X. (2016). Thinking about the positive impact of situational teaching on senior high school mathematics teaching. Asia Pacific Education, 24, 66-81.

Wyatt, R. C., \& Meyers, L. S. (1987). Psychometric properties of four 5-point Likert-type response scales. Educational and Psychological Measurement, 47, 27-35. https://doi.org/10.1177/0013164487471003

Yang, C. (2010). Nie Guojuan the application of "autonomous learning, cooperative inquiry" 


\section{Macrothink}

International Journal of Human Resource Studies

ISSN 2162-3058

2021, Vol. 11, No. 4S

teaching mode in junior middle school mathematics classroom teaching. Educational Research, (05).

Yang, G. (2013). On the implementation strategy of the cooperative learning mode of junior high school mathematics. China's out-of-school education: mid, (9), 21-21.

Yang, W. (2003). Research and experiment of cooperative learning in high school chemistry, graduation thesis of Master of Education, East China Normal University, 13-14.

Yao Kaiping, development, and response of the Taiwan version of the WHO quality of life questionnaire [DB / OL]. Http: / / wwwwww. doc88. com / p-304240607703. html, accesed at, $2015,(5)$.

Yuliani, K., \& Saragih, S. (2015). The Development of Learning Devices Based Guided Discovery Model to Improve Understanding Concept and Critical Thinking Mathematically Ability of Students at Islamic Junior High School of Medan. Journal of education and practice, 6(24), 116-128.

Zaini, S. N. M., Rami, A. A. M., Arsad, N. M., \& Anuar, M. A. M. (2021). Relationship of Academic Performance and Academic Self-Concept with Career Decision-Making among UPM Undergraduate Students. Asian Journal of University Education, 17(2), 50-61. https://doi.org/10.24191/ajue.v17i2.13403

Zakaria, E., Chin, L. C., \& Daud, M. Y. (2010). The effects of cooperative learning on students' mathematics achievement and attitude towards mathematics. Journal of social sciences, 6(2), 272-275. https://doi.org/10.3844/jssp.2010.272.275

Zhang Y., (2010). Talking about how teachers cultivate students' independent learning ability in teaching. The growth of teachers in China's out-of-school education, 2010(8).

Zhang, D., \& fan Guorui, (2014). Gender differences in classroom teaching: a case study of Shanghai primary school classroom, 35(4), 122-128158.

Zhang, X. (2012). Analysis of inquiry evaluation method of middle school mathematics. Gansu Education, (14), 40.

Zhao Y., (2014). Research on the construction of all staff cooperation mode, Shandong Social Sciences, January 2014.

Zhao, C. (2011). On how to cultivate students' autonomous learning ability in junior middle school mathematics teaching. Science Weekly, 2011(8).

Zheng, X., Feng, J., Chen, Y., Peng, H., \& Zhang, W. (2017). Learning context-specific word/character embeddings. In Proceedings of the AAAI Conference on Artificial Intelligence, 13(1), 65-75. 


\section{Copyright Disclaimer}

Copyright for this article is retained by the author(s), with first publication rights granted to the journal.

This is an open-access article distributed under the terms and conditions of the Creative Commons Attribution license (http://creativecommons.org/licenses/by/4.0/). 